\title{
A Journal of
}

\section{Zeitschrift für Naturforschung C}
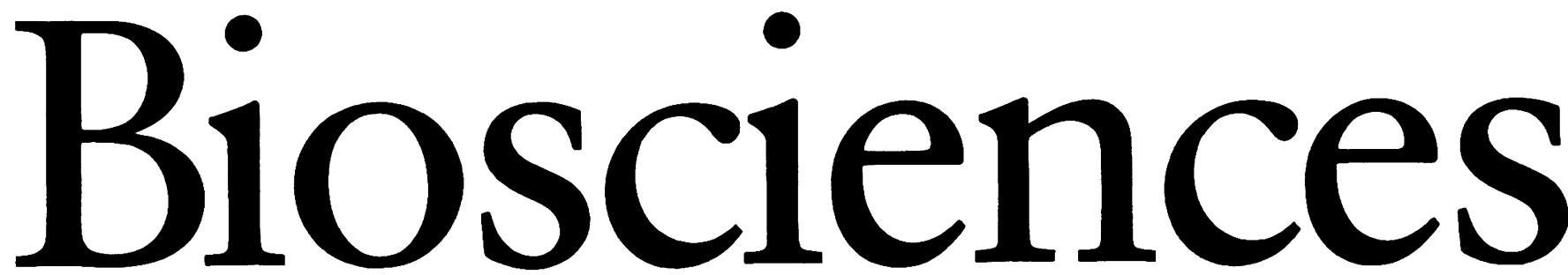

Founded 1946 in the Institutes

Volume 47

1992 of the Max-Planck-Gesellschaft

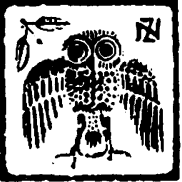

Verlag der Zeitschrift für Naturforschung 


\section{Invited Trends Article}

Sialic Acid-Binding Proteins: Characterization, Biological Function and Application F.-Y. ZENG and H.-J. GABIUS

\section{Original Communications}

Flavone-C-Glycosides from the Mosses Plagiomnium elatum and Plagiomnium cuspidatum

S. Anhut, J. Biehl, T. Seeger, R. Mues, and H. D. ZINSMEISTER

654

Chemical Composition and Surface Structures of Epicuticular Leaf Waxes from Castanea sativa and Aesculus hippocastanum

P.-G. GÜlz, E. Müller, and T. HeRrmanN 661

3',3'"-Binaringenin, a New Biflavonoid from Pilotrichella cuspidata (Meteoriaceae, Musci)

T. SEeger, H. Geiger, H. D. Zinsmeister, J.-P.

FraHM and L. WITTE

667

Purification and Characterization of Nitrate Reductase from the Halophile Archaebacterium Haloferax mediterranei

M. C. Alvarez-Ossorio, F. J. G. Muriana, F. F. DE LA Rosa, and A. M. RELIMPIO 670

Substrate Specificity of Tea Leaf Hydroperoxide Lyase
A. Hatanaka, T. Kajiwara, K. Matsui, and
H. TOYOTA
677

Sinapoylglucose : Malate Sinapoyltransferase Activity in Arabidopsis thaliana and Brassica rapa

H.-P. Mock, Th. VogT, and D. STRACK 680

Growth Responses to Flooding and Recovery of Deciduous Trees

J. FrYE and W. Grosse

The Growth of Freshwater Green Algae in Weak Alternating Magnetic Fields of $7.8 \mathrm{~Hz}$ Frequency

A. PAzur and H. ScheER

690

Saline Growth Conditions Favour Supercooling and Increase the Freezing Tolerance of Leaves of Barley and Wheat

M. Bender, U. Heber, and K.-J. Dietz 695
Extracellular Production of Abscisic Acid by Soil Algae under Salt, Acid or Drought Stress

B. MARŠÁLEK, H. ZAHRADNíČKOVÁ, and M. HRONKOVÁ

701

Inhibition by Cytokinin of the Accumulation of Betacyanin in Suspension Cultures of Phytolacca americana

H. Hirano, M.Sakuta, and A. Komamine 705

Differential Inhibition and Rephasing of Photosystem II Electron Acceptor Side by Monohalogenated Acetates of Different Hydrophobicity

CH. Xu, Y. ZHU, and GovindJeE

711

Maintenance of Photophosphorylation Despite Inhibition of the Transthylakoid $\mathrm{pH}$ Gradient by Tetracaine

H. LAASCH

The Effect of Ecdysterone on the Cyanobacterium Nostoc 6720

B. MarŚáleK, M. ŠimeK, and R. J. SMith 726

Purification of Antiviral Proteins with RibosomeInactivating Properties from Plants

M. SCHÖNFELDER, U. JANOTT, R. FRÖTSCHL, K.-W. Mundry, and G. Adam

731

A Simplified Combination of DNA Probe Preparation and Fluorescence in situ Hybridization D. Celeda, U. Bettag, and Ch. Cremer 739

Red Blood Cell Partitioning of the [6S]- and the $\left[6 R\right.$ ]-Isomer of $\mathrm{N}_{5}$-Formyltetrahydrofolic Acid M. J. CzejKa, J. Schüller, and W. ScheitHAUER

748

Effect of Cinnamic and Acrylic Acids' Derivatives on Luminol-Enhanced Chemiluminescence of Neutrophils

Z. Czuba, W. Krol, S. Scheller, and J. Shani

Electrostatic Potential Barrier in Asymmetric Planar Lipopolysaccharide/Phospholipid Bilayers Probed with the Valinomycin- $\mathrm{K}^{+}$Complex

U. Seydel, W. Eberstein, G. Schröder, and

K. BRANDENBURG

757

Continued overleaf 
Micromorphometric Evaluation of Changes in Symmetry of Sarcoplasmic Reticulum Membranes Induced by Vanadate K. Kranzhöfer, B. Agostini, L. De Martino, and W. HASSELBACH

762

\section{Notes}

Analysis of Phenolics of Bud Exudate of Populus violascens by GC-MS

W. Greenaway, J. May, T. Scaysbrook, and F. R. WhatLeY
Analysis of Phenolics of Bud Exudate of Populus laurifolia by GC-MS

W. Greenaway, J. May, and F. R. Whatley

Isolation of the New (-)-(3R,4S)-4-Hydroxymellein from the Fungus Septoria nodorum Berk M. Devys, M. Barbier, J.-F. Bousquet, and A. KollmanN 779

Exudate Flavonoids of Some Salvia and a Trichostema Species

E. Wollenweber, M. Dörr, A. Rustaiyan, J. N. Roitman, and E. H. Graven 


\title{
The Growth of Freshwater Green Algae in Weak Alternating Magnetic Fields of $7.8 \mathrm{~Hz}$ Frequency
}

\author{
Alexander Pazur and Hugo Scheer \\ Botanisches Institut der Universität, Menzinger Straße 67, \\ D-W-8000 München 19, Bundesrepublik Deutschland \\ Z. Naturforsch. 47 c, 690-694 (1992); received April 13/July 7, 1992 \\ Earth Magnetic Field, Schumann Resonance, Chlorella, Scenedesmus, Chlamydomonas, \\ Chlorophyll \\ Liquid cultures of Chlorella kessleri, Scenedesmus armatus and Chlamydomonas reinhardtii \\ have been grown phototrophically in weak $(0.2-2 \mathrm{G})$ alternating $(7.8 \mathrm{~Hz})$ magnetic fields. The \\ data indicate, that the rate of cell division is larger at 0.2 than at $2 \mathrm{G}$, viz. that the higher fields \\ have inhibitory effects on cell division and that there is possibly an optimum at $\approx 1 \mathrm{G}$. No reli- \\ able effect is found on the pigment contents.
}

\section{Introduction}

Static and low frequency alternating (electro)magnetic fields are components of the natural, but increasingly also of the man-made environment. Biological effects of such fields have mostly been studied with animals with a focus on sensory and on possibly harmful effects [1-4]. Work with plants is still comparably rare [5-11].

There are wide local and temporal fluctuations in the strength, direction and spectrum of electromagnetic fields, but few are universal. One such field is the so-called Schumann resonance, a standing electromagnetic wave between the surface of the earth and higher strata of the atmosphere [1213]. The ground-mode of this global electromagnetic field has a frequency of $7.8 \mathrm{~Hz}$ and it is fed by processes of strong ionization on the surface of the earth (e.g. thunderstorms) and ionizations, which result from interactions of high energy particles from outer space with the upper atmosphere and the earth's magnetic field.

We have recently begun to study magnetic field effects on plant and algal growth and development, and concentrated on some characteristic frequencies. Here we wish to report results which indicate, that alternating magnetic fields with a frequency of the Schumann ground-mode, $7.8 \mathrm{~Hz}$,

Abbreviations: Chl $a, b$, chlorophyll $a$ and $b$, rsp; Car, carotenoids; HPLC, high performance liquid chromatography.

Reprint requests to $\mathrm{H}$. Scheer.

Verlag der Zeitschrift für Naturforschung, D-W-7400 Tübingen $0939-5075 / 92 / 0900-0690 \$ 01.30 / 0$ and strengths $<2 \mathrm{G}$ show inhibitory effects on the growth of several freshwater green algae.

\section{Materials and Methods}

Algae

Chlorella kessleri (Fott et Novàkà, 211-11 h), Scenedesmus armatus (Chodat, 276-4c) and Chlamydomonas reinhardtii (Dangeard, 11-32b), were obtained from the "Algenbank der Universität Göttingen". Stock cultures were cultivated in liquid medium (after [14] for Chlorella and Scenedesmus, TAP medium after [15] for Chlamydomonas) under the light (2500 lux) of fluorescent tubes (Osram L $36 \mathrm{~W} / 25$ and Phillips TLD L $36 \mathrm{~W} / 25$ ). No attempts were made for synchronization.

\section{Experimental set-up}

Prior to the experiment proper, freshly inoculated algae were grown in 21 flasks for 7-10 days. $50 \mathrm{ml}$ of this preculture, which was still in the log phase, was then diluted $1: 10$ into fresh medium, and aliquots transferred immediately into 10 (8 in one experiment) sterile test tubes $(18 \times 1.8 \mathrm{~cm})$, which were plugged with sterile cotton wool. The cell densities, which were identical within the statistical error limits of the counting procedure (standard deviation $4.5 \%$ ), were in the range of $0.3-3 \times 10^{5}$ cells $/ \mathrm{ml}$ for Chlorella, $0.8 \times 10^{5}$ cells/ $\mathrm{ml}$ for Scenedesmus and $0.56 \times 10^{5}$ cells $/ \mathrm{ml}$ for Chlamydomonas (Table I). These culture tubes were arranged along the symmetry plane of 2 rectangular Helmholtz coils $(6 \times 20 \mathrm{~cm})$, which were positioned in a V-shaped geometry (Fig. 1). The latter produced a roughly linear magnetic field 
Table I. Cell division rates during the individual experiments. The cell division rates $\left(\mathrm{k}\left[\mathrm{d}^{-1}\right] \pm\right.$ standard deviation) for each individual tube were averaged over the 5 day growth period. Experiments 1-6 were done with Chlorella kessleri, experiment 7 with Scenedesmus quadricauda, and experiment 8 with Chlamydomonas quadricauda. The field strengths (B) are given on the left. For each individual experiment, the relation of cell division rates to the magnetic field strength were fit by a straight line. The fit parameters and the correlation coefficients are given together with the cell densities on day 1 at the bottom. A graphical evaluation of one sample experiment is shown in Fig. 2.

\begin{tabular}{|c|c|c|c|c|}
\hline $\begin{array}{l}\text { B } \\
{[G]}\end{array}$ & 1 & Exper & ${ }_{3}^{e n t ~ N o . ~}$ & 4 \\
\hline $\begin{array}{l}0.6 \\
0.8 \\
1.0 \\
1.2 \\
1.4 \\
1.6 \\
1.8 \\
2.0\end{array}$ & $\begin{array}{l}0.51 \pm 0.19 \\
0.57 \pm 0.21 \\
0.53 \pm 0.16 \\
0.64 \pm 0.18 \\
0.49 \pm 0.11 \\
0.48 \pm 0.12 \\
0.46 \pm 0.10 \\
0.50 \pm 0.09 \\
0.54 \pm 0.10 \\
0.59 \pm 0.08\end{array}$ & $\begin{array}{l}0.33 \pm 0.15 \\
0.25 \pm 0.14 \\
0.19 \pm 0.07 \\
0.32 \pm 0.16 \\
0.33 \pm 0.08 \\
0.31 \pm 0.14 \\
0.18 \pm 0.07 \\
0.25 \pm 0.11 \\
0.23 \pm 0.05 \\
0.18 \pm 0.07\end{array}$ & $\begin{array}{l}0.59 \pm 0.12 \\
0.51 \pm 0.08 \\
0.60 \pm 0.14 \\
0.62 \pm 0.06 \\
0.77 \pm 0.09 \\
0.62 \pm 0.10 \\
0.45 \pm 0.10 \\
0.53 \pm 0.13 \\
0.51 \pm 0.16 \\
0.43 \pm 0.13\end{array}$ & $\begin{array}{l}2.61 \pm 0.55 \\
2.61 \pm 0.58 \\
2.45 \pm 0.33 \\
2.56 \pm 0.55 \\
2.40 \pm 0.53 \\
2.72 \pm 0.41 \\
2.39 \pm 0.52 \\
2.25 \pm 0.64 \\
2.03 \pm 0.56 \\
1.97 \pm 0.63\end{array}$ \\
\hline $\begin{array}{l}\mathrm{N}^{\prime} \\
\mathrm{a}^{2} \\
\mathrm{~b}^{3} \\
\mathrm{r}^{4}\end{array}$ & $\begin{array}{l}1.4 \pm 0.04 \\
-0.004 \\
0.512 \\
-0.125\end{array}$ & $\begin{array}{l}1.1 \pm 0.07 \\
-0.011 \\
0.211 \\
-0.381\end{array}$ & $\begin{array}{l}1.1 \pm 0.07 \\
-0.015 \\
0.494 \\
-0.28\end{array}$ & $\begin{array}{r}2.7 \pm 0.12 \\
-0.067 \\
2.097 \\
-0.758\end{array}$ \\
\hline $\begin{array}{l}\text { B } \\
{[G]}\end{array}$ & 5 & Experir & $\underset{7}{\operatorname{ment}}$ No. & 8 \\
\hline $\begin{array}{l}0.2 \\
0.4 \\
0.6 \\
0.8 \\
1.0 \\
1.2 \\
1.4 \\
1.6 \\
1.8 \\
2.0\end{array}$ & $\begin{array}{l}0.30 \pm 0.07 \\
0.36 \pm 0.08 \\
0.44 \pm 0.08 \\
0.30 \pm 0.05 \\
0.30 \pm 0.09 \\
0.36 \pm 0.05 \\
0.38 \pm 0.09 \\
0.35 \pm 0.07 \\
0.30 \pm 0.06 \\
0.26 \pm 0.07\end{array}$ & $\begin{array}{l}0.96 \pm 0.17 \\
1.16 \pm 0.19 \\
0.99 \pm 0.26 \\
1.11 \pm 0.30 \\
0.97 \pm 0.29 \\
1.06 \pm 0.29 \\
0.85 \pm 0.27 \\
0.81 \pm 0.19 \\
0.82 \pm 0.19 \\
0.74 \pm 0.28\end{array}$ & $\begin{array}{l}0.42 \pm 0.13 \\
0.33 \pm 0.09 \\
0.60 \pm 0.15 \\
0.74 \pm 0.16 \\
0.52 \pm 0.15 \\
0.62 \pm 0.13 \\
0.28 \pm 0.08 \\
0.35 \pm 0.13 \\
0.35 \pm 0.12 \\
0.37 \pm 0.10\end{array}$ & $\begin{array}{l}2.09 \pm 0.42 \\
2.15 \pm 0.42 \\
1.96 \pm 0.50 \\
2.06 \pm 0.43 \\
1.89 \pm 0.42 \\
2.05 \pm 0.22 \\
1.66 \pm 0.36 \\
1.59 \pm 0.42 \\
1.40 \pm 0.36 \\
1.33 \pm 0.42\end{array}$ \\
\hline $\begin{array}{l}\mathrm{N}{ }^{1} \\
\mathrm{a}^{{ }^{2}} \\
\mathrm{~b}^{3} \\
\mathrm{r}^{4}\end{array}$ & $\begin{array}{l}3.0 \pm 0.05 \\
-0.006 \\
0.31 \\
-0.491\end{array}$ & $\begin{array}{l}0.3 \pm 0.01 \\
-0.036 \\
0.789 \\
-0.55\end{array}$ & $\begin{array}{l}0.5 \pm 0.04 \\
-0.018 \\
0.382 \\
-0.294\end{array}$ & $\begin{array}{l}0.03 \pm 0.82 \\
-0.011 \\
1.412 \\
-0.39\end{array}$ \\
\hline
\end{tabular}

1 Cell densities (cells $\times \mathrm{ml}^{-1}$ ) $\times 10^{-5}$ at the beginning of the experiment after dilution of stock culture. Aliquots of the suspension were divided into the test tubes, and each tube counted individually. The standard deviations represent the variation of cell densities on day 1 .

$2,3 \mathrm{a}$ and $\mathrm{b}$ are the factor and the constant of the linear regression graph $y=a x+b$.

$4 \mathrm{r}$ is the linear correlation coefficient. gradient from 0.2 to $2 \mathrm{G}$ in the experimental area. Cultures and coils were placed in a water bath and thermostated at $23^{\circ} \mathrm{C}$. They were irradiated by one fluorescent tube (Osram L $36 \mathrm{~W} / 25$ ) and 8 incandescent lamps (Osram, $75 \mathrm{~W}$ each) to produce a (nominal) light flux of 2500 lux. The local sinusoidal magnetic field strength was determined by a home built portable semiconductor Hall detector. The alternating current for the coils was generated by a home built multifunctional digital generator and amplified by a hybrid power amplifier. No provisions were made to shield the local magnetic field of the earth (about $0.65 \mathrm{G}$ ) and other environmental fields $(\leq 0.1 \mathrm{G})$, which provided a com- 
mon background to the applied magnetic fields. Cells were agitated once per day before sampling. Sedimentation was not observed in the intervening time span. The tubes were not aerated or supplemented with $\mathrm{CO}_{2}$. The run time of each single experiment (of a total of 8 with 3 different algae) was 5 days. The following parameters were recorded daily:

1. Cell density (cells $/ \mathrm{ml}$ ) was determined by removing $1 \mathrm{ml}$ aliquots under sterile conditions, and counting under the microscope. Values given are averages of 10 independent determinations $(1 \mu \mathrm{l}$ each).

2. In a total of 4 experiments, the pigment composition was additionally determined by HPLC. The system consisted of a Gynkotek pump (model $300 \mathrm{C})$ and a $5 \mu \mathrm{RP} 18$ column $(0.46 \times 25 \mathrm{~cm}$, Alltech-RSL, elution with $90 \%$ methanol $10 \%$ water, flow rate $1.5 \mathrm{ml} / \mathrm{min}$ ). The detection was done with a UV-VIS NIR diode array detector (HewlettPackard, HP 8451 A) set to the wavelengths of $360,410,436,460,470,500,640$ and $660 \mathrm{~nm}$, and controlled by a home-written program.

Data evaluation was done with Supercalc 5 (Computer Associates).

\section{Results}

Electromagnetic fields of frequencies as low as $7.8 \mathrm{~Hz}$ can not be generated easily in the laboratory. In the current work, the magnetic component was generated by two Helmholtz coils. The latter were arranged such that a series of test tubes could be exposed to fields in the range of $H_{\max }<2 \mathrm{G}$ (Fig. 1). This arrangement allowed for the simultaneous growth of up to 10 cultures within a field gradient. It has the advantage, that temporal variations of environmental parameters, which may otherwise perturb the data, are equally experienced by all samples.

The average cell multiplication rate was $1.13 \mathrm{~d}^{-1}$ (relative units, $\sigma=0.14$ ) for Chlorella and Scenedesmus and $2.53 \mathrm{~d}^{-1}(\sigma=0.22)$ for Chlamydomonas, the absolute cell densities at the beginning of the actual experiment (after transfer to the field chamber) were in the range of $0.3-3 \times 10^{6} \mathrm{cells} / \mathrm{ml}$ for Chlorella, $0.8 \times 10^{5}$ cells $/ \mathrm{ml}$ for Chlamydomonas and $0.56 \times 10^{5}$ cells $/ \mathrm{ml}$ for the much larger Scenedesmus.

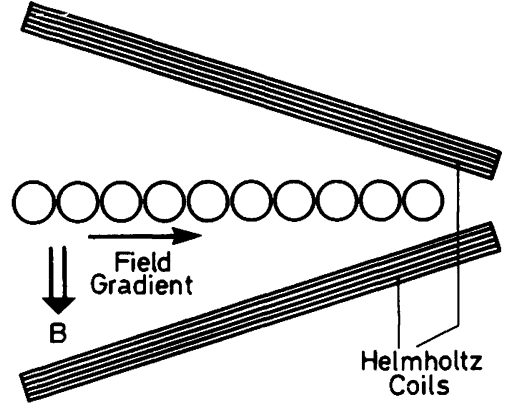

Fig. 1. Scheme of the V-shaped arrangement of the 2 Helmholtz coils (top view). The tubes containing the algal suspensions are indicated by circles. Coil size $=$ $20 \mathrm{~cm} \times 6 \mathrm{~cm}$

The growth rates of the different experiments (as measured by cell division) showed considerable scatter over the individual tubes (Table I and Fig. 2). However, most of the experiments gave a common trend: The growth in the lower magnetic field regions appeared consistently higher than in higher magnetic field regions.

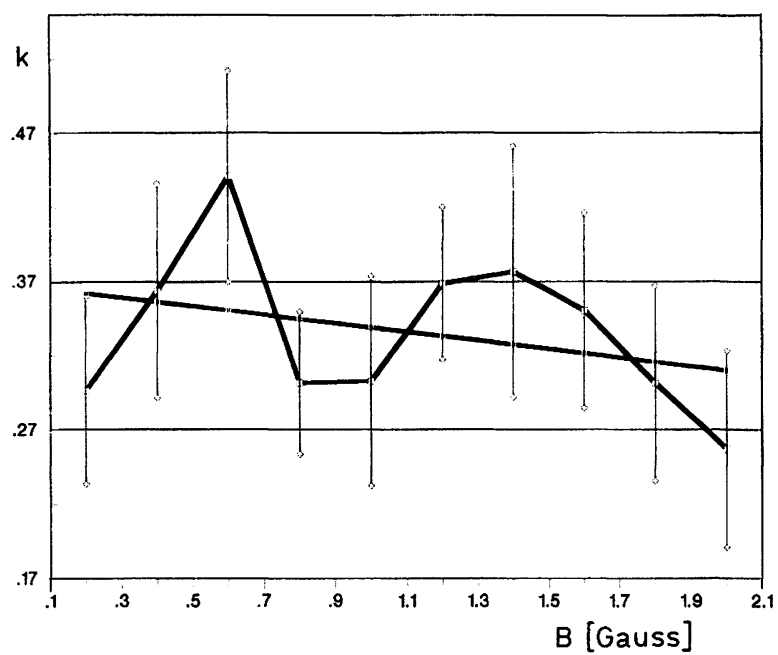

Fig. 2. Sample growth curve (taken from experiment 5) to indicate the scatter of individual experiments. The cell division rates $\left(k\left[\mathrm{~d}^{-1}\right] \pm\right.$ standard deviation) for each individual tube were averaged over the 5 day growth period. The straight line gives a linear fit for the relation of the cell division rates to the field strengths. A summary for all individual experiments, evaluated by the same method, is given in Table I. 


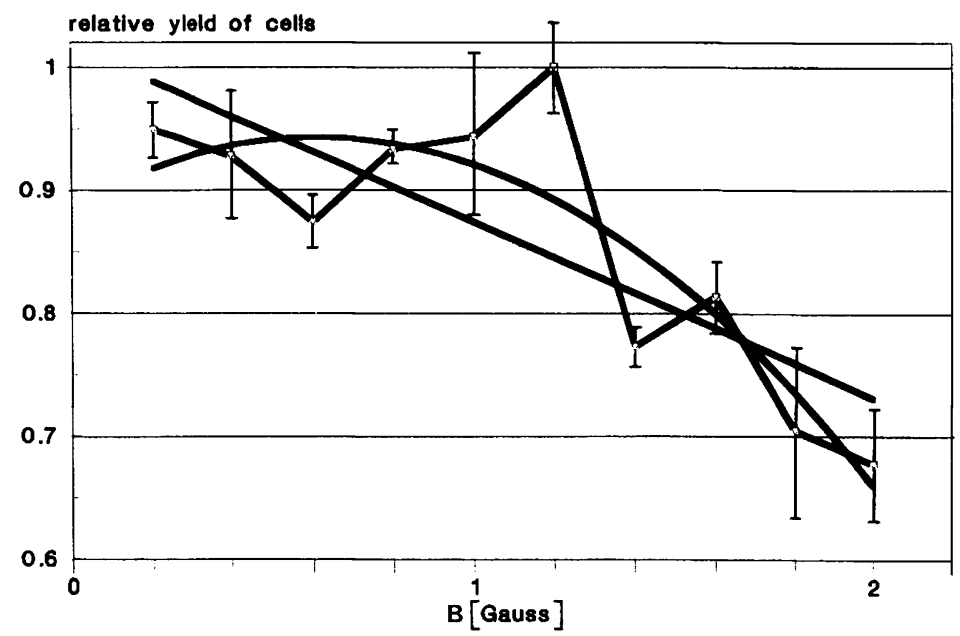

Fig. 3. Increase in cell density of Chlorella kessleri. Results for each day were first normalized to the tube with maximum cell density (set to 1) and then averaged over days $1-5$ of each individual experiment, and finally averaged over all 6 independent experiments (see also text for details). The bars give the standard deviations. A linear and quadratic fit is superimposed over the data.
This trend becomes more pronounced if the average over all experiments is taken for the samples grown under the same field strength. Fig. 3 shows these data for the 6 independent experiments conducted with Chlorella. Several fits of the data were tested. The best linear fit shows a decrease by approx. $10 \%$ when going from 0.2 to $2 \mathrm{G}$ field strength, which must be compared with a standard deviation (averaged over the different field positions) of 0.077 . A better fit is obtained by a quadratic function, which peaks at about $1 \mathrm{G}$. However, in the absence of a working hypothesis this gives only a mathematical description of the data, and only a much more detailed analysis can give a more precise function.
Fig. 4 shows the combined data obtained with Scenedesmus and Chlamydomonas when treated in the same way. In this case the averages represent (normalized) data from 2 experiments with the 2 organisms. The decrease according to the best linear fit is $25 \%$ in the field range investigated (average standard deviation of 0.064 ). A quadratic function peaking at about $0.7 \mathrm{G}$ gives again a somewhat improved fit. We take the results with all three organisms as an indication that the growth of the alga investigated, is effected by the applied alternating magnetic field.

During four experiments, the chlorophyll contents and the Chl $a / b$ ratios were determined daily for every culture (group). The data (not shown)

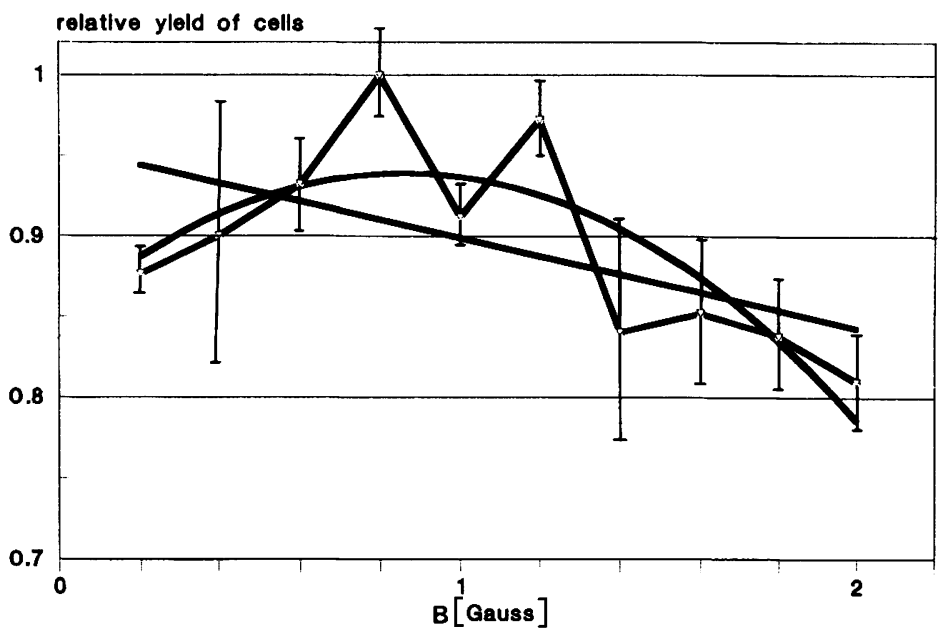

Fig. 4. Increase in cell density of Scenedesmus armatus and Chlamydomonas reinhardtii. Results for each day were first normalized to the tube with maximum cell density (set to 1 ), then averaged over days 1-5 of each individual experiment, and finally averaged over the independent experiments (for details see Fig. 3 and text). 
have a very strong scatter due to the small sample volumes available. Even if sometimes the same trend as for cell growth is indicated, there is no obvious correlation possible on this basis.

\section{Discussion}

Halpern [16] has studied the growth of Chlorella and Euglena in weak static magnetic fields. $\mathrm{He}$ gives only data for two ranges of field strengths: $<10 \mathrm{G}$ and $>10 \mathrm{G}$. Algae, which were grown by exposition in the lower field showed an accelerated growth in comparison with the cultures exposed to the higher field. In the experiments presented here, cell division was consistently less at the highest magnetic fields used $(2 \mathrm{G})$ than at the lowest fields $(0.2 \mathrm{G})$. Combined with the results presented here, these data indicate, that static as well as alternating weak magnetic fields have inhibitory effects on the growth of green algae.

The molecular origin for the effects of weak magnetic fields on living matter are currently still unclear. The only well established mechanism is related to the presence of small magnetic particles,

[1] A. S. Presman, Electromagnetic Fields and Life, Plenum Press, New York, London 1970.

[2] Environmental Health Criteria, Vol. 69: Magnetic Fields, p. 16-25, World Health Organization, Geneva 1987.

[3] Environmental Health Criteria, Vol. 35: Extremely low Frequency Fields, p. 32-50, World Health Organization, Geneva 1984.

[4] F. E. Senftle and W. P. Hambright, in: Biological Effects of Magnetic Fields, Vol. 1 (M. F. Barnothy, ed.), pp. 266-269, Plenum Press, New York 1964.

[5] D. W. Dunlop and B. L. Schmidt, in: Biological Effects of Magnetic Fields, Vol. 2 (M. F. Barnothy, ed.), pp. 149-170, Plenum Press, New York 1969.

[6] S. F. Jackson, Biophysical studies of pulsed magnetic field interaction with biological systems, Part 1 (S. F. Jackson, ed.), pp. 537-545, Strangeways Research Laboratory, Cambridge, U.K. 1979.

[7] H. L. König, Unsichtbare Umwelt, der Mensch im Spielfeld elektromagnetischer Feldkräfte, 5. Aufl., pp. 119-125, Eigenverlag H. L. König, München 1986.

[8] R. Kato, Plant Cell Physiol. 29, 1215-1218 (1988).

[9] R. Kato, Plant Cell Physiol. 31, 565-568 (1990).

[10] F. F. Torres de Araujo, M. A. Pires, R. B. Frankel, and C. E. M. Bicudo, Biophys. J. 50, 375-378 (1986).

[11] R. Kato, H. Kamada, and M. Asashima, Plant Cell Physiol. 30, 605-608 (1989).

[12] W. O. Schumann, Über die zeitliche Form und das Spektrum ausgesendeter Dipolstrahlung in einer dielektrischen Hohlkugel mit leitenden Wänden mit besonderer Anwendung auf atmosphärische Signale, e.g. in magnetobacteria [17]. To our knowledge, there are no reports on such particles in the algae investigated. Glaser [18] has investigated the electric coupling of cell membranes. When his theory is applied to cells the size of Chlorella, a response to low frequency fields $(1-200 \mathrm{~Hz})$ could be expected [19]. However, this would not explain the results of Halpern [16] with static fields. Another magnetic field effect is known for reactions involving the formation of triplet states by the "radical pair mechanism" (see e.g. [20, 21]). However, these fields are stronger than the ones applied in this study, by 1-2 orders of magnitude. In addition to these "classical" mechanisms, coherent properties of living matter have been invoked e.g. by Warnke and Popp [22], but again there is currently no established structural basis. Obviously in spite of a growing evidence for magnetic field effects, much more work will be needed to understand their origins.

\section{Acknowledgements}

A. P. acknowledges a stipend from the HannsSeidel-Stiftung, München.

Verlag der Bayerischen Akademie der Wissenschaften, München 1956.

[13] C. F. Blackmann, in: Interactions between Electromagnetic Fields and Cells (A. Chiabrera, C. Nicolini, and H. P. Schwan, eds.), Life Sciences (NATO ASI Series A) 97, 217-231 (1983).

[14] M. J. Geoghegan, Carnegie Inst. Wash. Publ. 600, 182-189 (1953); cited in: B. H. Ketchum, Annu. Rev. Plant Physiol. 5, 55-74 (1954).

[15] J. D. Rochaix, S. Mayfield, M. Goldschmidt-Clermont, and J. Erickson, in: Plant Molecular Biology (C. H. Shaw, ed.), pp. 253-275, IRL Press, Oxford, Washington D.C., 1988.

[16] E. Halpern, in: Biological Effects of Magnetic Fields, Vol. 2 (M. F. Barnothy, ed.), p. 235, Plenum Press, New York 1969.

[17] R. B. Frankel and P. Blakemore, Bioelectromagnetics 10, 223-235 (1989).

[18] R. Glaser, Biophysik, 3. Aufl., pp. 308-310, Ulmer Verlag, Stuttgart 1982.

[19] A. Pazur, Dissertation, München 1991.

[20] S. Boxer, C. E. D. Chidsey, and M. G. Roelofs, Annu. Rev. Phys. Chem. 34, 389-417 (1983).

[21] A. Ogrodnik, H. W. Krüger, H. Orthuber, R. Haberkorn, and M. E. Michel-Beyerle, Biophys. J. 39, 91-99 (1982).

[22] U. Warnke and F. A. Popp, in: Electromagnetic Bioinformation (F. A. Popp, G. Becker, H. L. König, and W. Peschka, eds.), pp. 85-110, Urban \& Schwarzenbeck Verlag, München, Wien, Baltimore 1979. 